\title{
Identifying the Ethical Issues in Research and the Process of Gaining the Scientific Titles
}

\author{
Hasan Jashari \\ SEE University, Macedonia
}

\author{
Doi:10.5901/mjss.2015.v6n2s5p166
}

\begin{abstract}
Ethical issues in scientific research are very complex, in the same manner as they are delicate. In most of the cases, the researcher needs to collect data from people, in unknown conditions and circumstances with huge social, ethnical, cultural, religious and gender pressure. The issue of ethics in scientific research especially in gaining academic titles is primarily a matter of social practice. We are all witnessing that many research papers are written for scientific titles, and they're based on second and third hand resources, without any first hand research. 2/3 of Master and Doctoral candidates have gathered data from the projects where they did not participate; they have collected and used data from other known and unknown researchers. In Macedonia, the government has established a mechanism for saving and checking master and doctoral papers from 2012 (www. plagijati. com. m). This presents a good opportunity for checking the integrity and validity of the academic papers. The researcher's responsibility represents a huge problem. This last decade the government prompted the massive enrollment in the universities as an idea with value, but recently the question whether this is becoming devaluated now is more than questionable? How much the race for profit is influencing the ethical aspect of the scientific and pedagogical research? At this point do the government and the universities thrive to provide quality in the higher education? How much are involved the principles of Salzburg in the third cycle of studies? In Macedonia and neighbor countries there is a huge competition for gaining academic titles. The number of Doctoral holders in Macedonia in 2013 increased for 50. 5 \% compared to year 2012. By using the method of analyzing the documentation we'll gather and interpret data related to research ethics and copyrights of the scientific papers.
\end{abstract}

Keywords: Ethics, Research, Scientific Titles, Plagiarism

\section{Introduction}

Definition of ethics mostly focuses on the idea that it represents branch of philosophy which deals with moral principles that govern a person's behavior or conducting of an activity. Very often medical ethics also takes part in this definition. Ethics can also be defined as the branch of knowledge that deals with moral principles. But if we want to define the Research as a process, it has another definition. According to Cambridge Dictionary (2003) research it is a detailed study of a subject, especially in order to discover (new) information or reach a (new) understanding . There are many different aspects of research which include: the detailed study of something in order to discover new facts, especially in a university or scientific institution

Other definitions are based on some points and different authors have different opinions how they view this issue. Some think that the research represents making a rigorous and relevant contribution to knowledge. Others define it as a relationship among point $A$ with point $B$, and by linking these two one new product- $C$ is created. Some others refer to it as an organized inquiry to provide information for the solution to a problem (Emery\&Cooper, 1991). According to Kumar (Kumar, 1996) the research is a careful and systematic investigation in some field of knowledge, undertaken to establish facts or principles). (Jung-Su Kim, 2006, p. 4)

\section{Methodology}

This paper is collecting factual data from several first and second hand resources as: literature review and statistical analysis of data of scientific titles in Macedonia. Also, the report of plagiarism from the software of the Ministry of Education and Sciences will be interpreted. (http: //plagijati. mon. gov. mk)

The data will be interpreted through tables and average percentages. 


\section{Some History and Actual Debates}

Ethical issues in research are as old as humanity. Through time this issues have been defined with legal norms. It is clearly stated which are the processes of copyright, how to save personal and private data, what is called an original work and what is meant by an independent work. Here we have to deal with clarification of what is called our authentic work and how to cite sources used by other authors. Saint Simone and Auguste Compte ended their cooperation, just because of one publication which was not appropriately cited.

At the time of Reich third, the Nazis in the name of scientific research destroyed all ethical borders and tried to use Satanism. The research for genetically modified foods and genetic engineering are very debatable issues, as is the air pollution and those who gain economical benefits by damaging people's health.

The next question tries to find out whether the manipulations done by politicians during the elections can be used in the same way by the scientists as well? At least one minute within a week we need to stop and think about this issue.

All these issues produce many legal and moral norms, ethical codes, councils, committees and associations. But the social practice shows that we have many things to work on. We can check the scientific paper on the software in order to prove how many words or sentences are used from other authors, but we cannot prove whether the interviews are done correctly, whether the collected results of methods are done correctly and how useful they are?

Another question that we need to consider as ethical issue is whether there are any manipulations in the numbers of the collected data and are they influenced by our own believes? All this leads to definition of the data validity, and whether we create them or we are just participants of the project?

Many authors agree that to think for ethics means: : to recognize moral and social values which are related to social research, in particular to ask ourselves how do we need to treat the participants. If we refer to Matthews and Ross (Matthews and Ross, 2010, p. 73-81) we need to define in which way we can protect moral standards.

We can conclude that research ethics needs to begin with sincere and precise information, then to add the possible anticipated problems, explain in which way the data will be used, which is your status, validity of data, time needed for participation, copyright etc.

\section{Literature Review}

The scientific literature for moral issues of the researcher is very broad. A huge number of books and manuals are designed for researchers and students, in order to make them aware and increase the responsibility for data collection, selection and interpretation of facts. Probably this originates with Socrates quote: "know yourself" (Socrates on Know Thyself), and then Descartes with Cogito ergo sum ("I think, therefore I am"), Kant's categorical imperative etc.

For this paper we have elaborated and used information from the book: Plagiarism in scientific writing: words or ideas? (Hadzibadeh, F. , Sashok, K. , 2011, p. 576-577).

Plagiarism refers to the act of "appropriation of another person's ideas, processes, results, or words without giving appropriate credit". But, at the same time, students cheats in classroom, in exam, homework... Refers to Donald L. McCabe ( Mcabe et all, 2001, p. 228) "On many campuses the fundamental element of an academic code honor must be the particularly useful tools for colleges and universities who seek to reduce students cheating,

Most academic researchers reach a consensus that plagiarism is a serious breach of publication ethics . Plagiarism has different forms but can be categorized into two general distinct categories - plagiarism of ideas and plagiarism of text (verbatim). No doubt, plagiarism of ideas is a blatant act of misconduct. Plagiarism of text and recycling of words are also a serious fault in humanities and literature where the essence of work and novelty are wordings and eloquence of the text. But, what about science where the essence of the work is the originality of the scientific content no matter how eloquent it is presented. (http: //www. ncbi. nlm. nih. gov).

There are some authors who think that schools of ethics in Western Philosophy can be divided, very roughly into three sorts. The first, drawing on the work of Aristotle, holds that the virtues (such as justice, charity, and generosity) are dispositions to act in ways that benefit both the person possessing them and that person's society. The second, defended particularly by Kant, makes the concept of duty central to morality ( http: //www. oxforddictionaries. com/definition)

Rosycki in his book Plagiarism (2001, p. 7) states that in our everyday life we often do not need to point from where we have taken the information, they just need to follow an interesting story. This differs at schools. Teachers need to know precisely where you got the information and facts, how you interpret them, and most importantly whether they are your or somebody else's ideas.

Therefore, they need to know the source of the information or the author of the paper, information or idea. This leads toward plagiarism. This is a very serious issue, which very often creates trouble for academia. 


\section{How to Do a Scientific Research Including Ethics?}

Ethical issue in scientific research especially in gaining academic titles is an issue of social practice. We can all witness that there are many papers written only for gaining academic titles, with no first hand resources, only second and third hand data.

Plagiarism becomes more present with the massive use of internet in our everyday lives. Earlier when typing machines were used as writing tools there was bigger space for adding comment and suggestions, and nowadays it is easily done by adding and combining texts in much easier way with less effort.

On the other hand, based on many social experiences a huge number of important people like state presidents, prime ministers, ministers, mayors and other public figures had to resign from their posts only because they have broken the ethical issues regarding the scientific titles. This phenomena is not present only in elite circles, but in all social layers. The only difference is that in the elite circles their political responsibility and social control makes them more visible, they are constantly criticized and followed by media and by representatives of public opinion.

Research cannot be done in one particular place, let say laboratory; instead it is done in social and natural environment.

If the research is not done with ethical reflection, it can be harmful. For example, collective data and analytical work with personal information can be very sensitive issue for the individuals as well as for the social groups. The same thing can be applied for the experimental work in general (including people or animals). Nowadays, the researcher needs to consider legal regulations (in educational research the legislation on data protection is probably the most common case), which define concrete barriers for: 'free research'. For these reasons, at these contemporary times there is a rapid increase of the value of research ethics and the issues of academic integrity.

The main principles of research ethics are often represented as follows: ( Zgaga et all,p. 50)

- Respect for human dignity (to be aware of the humanity of every person, treat people as you want to be treated and never treat them as a means for attaining personal purpose, consider human rights, etc. )

- Benefit (try to maintain quality; there is always a need to find ways for better use of resources, never misuse the participants of the research etc. )

- Justice (the importance of justice, equal access to benefits, respect for privacy, respect for individuals or disadvantaged groups, etc).

Researcher (or the research group), who should conduct the research, needs to respect completely the academic integrity that is required by him / her (them):

- To recognize the contribution of other sources in his/her research efforts;

- To complete an independent research work unless he/she is authorized to request or receive assistance in its preparation;

- To follow research guidelines and stick to standards of the given academic discipline; and

- To avoid, in any form academic cheating.

There is a tendency in all research universities to form committees for research ethics. All research projects where people are involved (sometimes there are researches where animals are involved) and are done by the Faculties, staff and students need to take ethical approval that the research can be conducted before the research begins. The majority of universities including the SEEU (South East European University) have defined their ethical code and the regulation for the scientific research.

Scientific research is closely related to morality and its definition means a habit, action or a behavior becoming a habit. The morality deals with law, tradition, decency, character and purity. In philosophical view the term moral is characterized with tradition, especially best practices which enable harmonious and productive existence of the individual in the society.

\section{Research Data}

Form 2012 in Macedonia with all changes in the law for higher education the criteria for gaining academic titles is becoming tougher. The Ministry of Education has database for each formal scientific work and it shows precisely the number of borrowed words from other scientific works. The Salzburg principles are updated, and more often they are used positively in all areas of the research methodology.

Below is presented a practical approach for avoiding plagiarism, used by the formal system of the Ministry of Education and Science. 
Table 1. South East European University Master and Doctoral students work checked in the Ministry Software for Plagiarism. (The cases are chosen randomly)

\begin{tabular}{|c|c|c|c|}
\hline Mentorship & Number of MA thesis & PhD thesis & Percentages of borrowed words from other scientific works: \\
\hline Professor nr 1 Mentor & 8 & 1 & 2,70 \\
\hline 2 & 14 & 1 & 1,92 \\
\hline 3 & 23 & 1 & 2,32 \\
\hline 4 & 17 & 2 & 3,02 \\
\hline 5 & 6 & 2 & 1,65 \\
\hline 6 & 8 & 0 & 2,11 \\
\hline 7 & 15 & 0 & 2,94 \\
\hline 8 & 12 & 0 & 2,30 \\
\hline Total; 8 & 96 MA thesis & 7 PhD Thesis & All: $2,37 \%$ \\
\hline
\end{tabular}

From these results we can conclude that this system is very practical, but it does not mean that the problem is solved totally. Obviously it helps the process, but the rest of the work depends on us-researchers, to develop self-control and self-responsibility for the academically scientific work. No significant difference between Master and Doctoral thesis related to the number of borrowed words from other scientific works. Percentages of borrowed words from other scientific works for 103 scientific works is 2,37. This result is low

Table 2. Masters of science according to the scientific field of the master's thesis, sex and age

\begin{tabular}{l|cc|c|c|c|c|}
\hline \multirow{2}{*}{} & \multicolumn{2}{|c|}{ Total } & \multicolumn{3}{|c|}{ Age groups } & \multirow{2}{*}{ All } \\
\cline { 2 - 7 } & & Female & $\begin{array}{c}29 \\
\text { Up to } 29\end{array}$ & $30-34$ & $35-39$ & $40+$ \\
\hline Total & 1558 & $\mathbf{8 9 5}$ & $\mathbf{8 2 9}$ & $\mathbf{2 8 9}$ & 194 & $\mathbf{2 4 6}$ \\
Natural sciences and mathematics & 67 & 35 & 31 & 15 & 7 & 14 \\
Technical-technological sciences & 283 & 98 & 158 & 48 & 30 & 47 \\
Medical sciences & 15 & 7 & 4 & 3 & 2 & 6 \\
Biotechnical sciences & 41 & 22 & 12 & 10 & 9 & 10 \\
Social sciences & 1012 & 636 & 553 & 181 & 125 & 153 \\
Humanities & 140 & 97 & 71 & 32 & 21 & 16
\end{tabular}

As described in table 2 for Masters of science and specialists, in 2013 according to the data of the State Statistical Office, a total of 1664 persons obtained the titles of Master of Science and Specialist, of which 1558 persons or 93. 6\% were masters of science and 106 persons or $6.4 \%$ were specialists. Compared with 2012, the number of masters of science and specialists increased by $6.1 \%$. The participation of women in the total number of masters of science in 2013 was 57. $4 \%$. In 2013 , the majority of master's theses, 1012 or $65 \%$, were in the field of social sciences, followed by $18.2 \%$ in the field of technical and technological sciences, while the rest were in the fields of humanities, natural sciences and mathematics, biotechnical and medical sciences. (http: //www. stat. gov. m 2015)

Table 3. Doctors of science according to the scientific field of the doctoral dissertation and age

\begin{tabular}{|c|c|c|c|c|}
\hline \multirow[b]{2}{*}{$\begin{array}{l}\text { Total } \\
\text { Natural sciences and mathematics } \\
\text { Technical-technological sciences }\end{array}$} & \multirow{2}{*}{$\begin{array}{r}\text { Total } \\
119\end{array}$} & \multicolumn{3}{|c|}{ Age groups } \\
\hline & & $\begin{array}{c}26-29 \\
16 \\
3 \\
1\end{array}$ & $\begin{array}{c}30-39 \\
110 \\
7 \\
17\end{array}$ & $\begin{array}{c}40+ \\
93 \\
6 \\
13\end{array}$ \\
\hline $\begin{array}{l}\text { Biotechnical sciences } \\
\text { Social sciences }\end{array}$ & $\begin{array}{l}11 \\
62\end{array}$ & $\begin{array}{c}1 \\
10\end{array}$ & $\begin{array}{l}7 \\
64\end{array}$ & $\begin{array}{c}6 \\
40\end{array}$ \\
\hline
\end{tabular}

Based on table 3, Doctors of science in 2013, according to the data of the State Statistical Office, 219 persons have gained the title "Doctor of Science", which is an increase of 50\% compared with 2012. The majority of doctorate holders, $52.1 \%$, have gained their doctorate in the field of social sciences, followed by $14.2 \%$ in technical-technological sciences, 11. $9 \%$ in the field of medical sciences, while the rest have obtained their doctorate in the field of humanities, natural 
sciences and mathematics and biotechnical sciences. The participation of females that have obtained a doctorate during 2013 was 119 candidates or 54 . 3\% of the total number of doctorates in 2013. Of the total number of persons that have gained the title Doctor of Science, the majority, 55. 7\%, work in educational activity.

\section{Documents Found with Similarities}

This table below presents a detailed report of the PhD candidate related to the work used by others. Their work, as well, needed to be checked before the defense in the Software of the Ministry. In this case the candidate has used data from his MA research in non-ethical way, so that in percentages he has used 1. $28 \%$ from his previously used work, and 0. $15 \%$ of the general material.

\section{Table 4.}

Candidate: Blerim Elezi

Prof. D-r. HasanJashari

February, 2015, 0106 Documents, 5 exposed documents

\begin{tabular}{|c|c|}
\hline Document from which are borrowed words, sentences ( MA thesis and the name of Author) & Results \\
\hline $\begin{array}{l}\text { SadinSaliu. doc } \\
\text { Author: Sadin Saliu }\end{array}$ & $\begin{array}{l}\text { 1. } 28 \% \text { [268/20880 words] } \\
39.64 \% \text { [268/676 words] }\end{array}$ \\
\hline $\begin{array}{l}\text { XhemaliLimaniMAgjistratura. doc } \\
\text { Author: Xhemali Limani }\end{array}$ & $\begin{array}{l}\text { 0. 93\% [195/20880 words }] \\
28.85 \%[195 / 676 \text { words }]\end{array}$ \\
\hline $\begin{array}{l}\text { SelimDaku. doc } \\
\text { Author: Selim Daku }\end{array}$ & $\begin{array}{l}\text { 0. } 47 \% \text { [98/20880 words] } \\
14.5 \%[98 / 676 \text { words] }\end{array}$ \\
\hline $\begin{array}{l}\text { DenisDika. doc } \\
\text { Author: Denis Dika }\end{array}$ & $\begin{array}{l}0.15 \%[31 / 20880 \text { words }] \\
\text { 4. } 59 \%[31 / 676 \text { words }]\end{array}$ \\
\hline $\begin{array}{l}\text { MAdissertation. doc } \\
\text { Author: Nazan Mustafa }\end{array}$ & $\begin{array}{l}\text { 0. } 14 \% \text { [29/20880 words }] \\
\text { 4. } 29 \%[29 / 676 \text { words }]\end{array}$ \\
\hline
\end{tabular}

\section{Conclusion}

Ethical issues in scientific research are very complex and not much elaborated. First of all, they represent very delicate social practice, and as the time is passing they become even more interesting and debatable. In Macedonia there is an increased trend that scientific works and research need to be sensible when it comes to personal care and responsibility. Statistical indicators show that the use of Principles of Salzburg need improvement, also there is a lack in transparency, innovation and research groups.

Everywhere, teachers, administrators, students should work together to reduce the cheating.

In the future this issue will be even more attacked from public opinion critics, the legislature and various codes of ethics.

\section{References}

Oliver, Paul (2010) . The students Guide to research ethics, Second Edition, University Press, McGraw -Hill, Education, New York Kim, Jung-Su (2006). Introduction to Scientific Research . Research Methods in Eng. , 2006 IST, Univ. of Stuttgart, page 4 State Statistical Office. Masters of science and specialists, 2013 (2014). Skopje, Dame Gruev 4, P. box 506 2014, page 1.

State Statistical Office Doctor of Science 2013 (2014) Skopje, Dame Gruev 4, P. box 506 2014, page 1.

Mattews B. ,Ross L. ,2010. Metodat e hulumtimit. Udhezues praktik per shkencat sociale dhe humane. cde. Tirane, page78-83.

Clabaugh. K\& Rozycky. G. , Edward (1999). The Plagiarism Book 2nd Edition, Publisher: New foundation.

Habibzedeh Farrokh,Shashok Karen (2011). Plagiarism in scientific writing: words or ideas?, Croatian Medical Journal. Aug; 52 (4): page576-577.

Gilmore Barry (2008). Plagiarism: Why It Happens and How to Prevent It. Paperback - Heinemann Hutchinson School, Memphis, Tennessee

Pavel Zgaga, Hasan Jashari,Lejla Abazi-Bexheti, Agim Poshka. (2011). Master of Education Students's Final Thesis Dissertation Handbook. In MA Handbooks, pp. 3. . SEEU, Tetove, Arberia Design, page 50.

Klebe L. ,Trevino \& Butterfield, D. Kennett, (2001) Cheating in Academic Institutions: A Decade of Research, Ethics \& Behavior, 11: 3 , 
219-232, page 228

Cambridge Dictionary ( 2003) Cambridge University Press . Macmillan Publishers Ltd. 2002.

Vessal K, Habibzadeh F. (2007);369: 641 Rules of the game of scientific writing: fair play and plagiarism. Lancet. . Journal of Microbiology \& Biology Education,

\section{References to Web Recourses:}

http: //plagijati. mon. gov. mk/userreports/h. jashari 10. 03. 2015

http: //www. ncbi. nlm. nih. gov/pmc/articles/PMC4278456/10. 03. 2015

http: //www. oxforddictionaries. com/definition/english/ethics, 07. 03. 2015) 